ISSN : 2580-3220, E-ISSN : 2580-4588

J. Mandiri., Vol. 4, No. 2, Desember 2020 (123 - 130)

(C)2018 Lembaga Kajian Demokrasi

dan Pemberdayaan Masyarakat (LKD-PM)

DOI : https://doi.org/10.33753/mandiri.v4i2.118

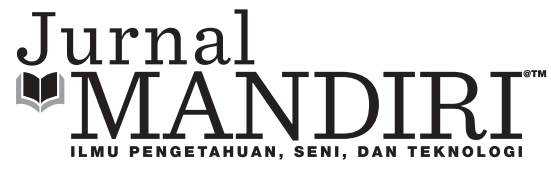

\title{
Penilaian Manfaat Nilai Ekonomi Program Penyediaan Air Minum dan Sanitasi Berbasis Masyarakat
}

\author{
Yustirania Septiani \\ Fakultas Ekonomi, Universitas Tidar \\ yustirania_septiani@untidar.ac.id \\ Gentur Jalunggono \\ Fakultas Ekonomi, Universitas Tidar \\ jalunggono@untidar.ac.id
}

\begin{abstract}
Abstrak
Program Penyediaan Air Minum Berbasis Masyarakat (Pamsimas) merupakan program pemerintah yang bekerjasama dengan daerah dan didukung oleh Bank Dunia terkait peningkatan akses layanan air minum, sanitasi, dan peningkatan kesehatan terutama dalam penyelesaian penyakit diare dan penyakit yang ditularkan melalui air dan lingkungan. Program ini membutuhkan anggaran yang besar sehingga disayangkan jika tidak membawa dampak yang positif pada masyarakat. Sehingga perlu adanya kajian mengenai dampak perbedaan program bagi masyarakat dan informasi mengenai efektivitas keberadaan program agar selain bermanfaat, masyarakat dapat bersama-sama berkontribusi dalam keberlanjutan program. Metode yang digunakan yakni uji binomial terkait perbedaan tingkat ketersediaan air bersih sebelum dan sesudah adanya program Pamsimas. Rasio efektivitas untuk melihat hubungan di antara output dan hasil akhir yang diharapkan. Semakin besar kontribusi output pada pencapaian hasil akhir, dapat dikatakan bahwa organisasi, program, atau kegiatan tersebut efektif. Hasil penelitian memperlihatkan terdapat perbedaan ketersediaan sarana air bersih di Desa Sudimara, Kecamatan Cilongok, Kabupaten Banyumas, Jawa Tengah sebelum dan setelah adanya program Pamsimas. Sedangkan berdasarkan 6 indikator keberhasilan memperlihatkan tingkat efektivitasnya hanya kriteria ke-5 yang berada pada kriteria efektif dan 5 indikator lainnya berada di kriteria sangat efektif. Simpulan program Pamsimas sudah optimal dan berhasil dalam penyediaan air bersih dan program ini juga dikatakan sangat efektif dalam pelaksanaan di Desa Sudimara, Kecamatan Cilongok, Kabupaten Banyumas, Jawa Tengah.
\end{abstract}

Kata Kunci : Uji Binomial, Rasio Efektivitas, Pamsimas

\begin{abstract}
The Community-Based Drinking Water Provision Program (Pamsimas) is a government program that collaborates with regions and is supported by the World Bank in terms of increasing access to drinking water, sanitation, and improving health, especially in solving diarrhea and water-borne and environmental diseases. This program requires a large budget so it is a shame if it does not have a positive impact on society. So it is necessary to study the impact of different programs for the community and information on the effectiveness of the program so that apart from being useful, the community can jointly contribute to the sustainability of the program. The method used is the binomial test related to differences in the level of clean water availability before and after the Pamsimas program. The ratio of effectiveness to see the relationship between output and the expected end result. The greater the output contribution to the achievement of the final result, it can be said that the organization, program or activity is effective. The results showed that there were differences in
\end{abstract}


the availability of clean water facilities in Sudimara Village, Cilongok District, Banyumas Regency, Central Java before and after the Pamsimas program. Meanwhile, based on 6 indicators of success, it shows the level of effectiveness, only the fifth criterion is in the effective criteria and the other 5 indicators are in the very effective criteria. The conclusion of the Pamsimas program has been optimal and successful in providing clean water and this program is also said to be very effective in its implementation in Sudimara Village, Cilongok District, Banyumas Regency, Central Java

Keywords : Binomial Test, Effectiveness Ratio, Pamsimas

\section{PENDAHULUAN}

Indonesia memiliki kondisi ketersediaan air bersih yang masih relatif minim dibanding negara yang lain. Persentase rumah tangga di Indonesia yang dapat mengakses air minum layak baik di pedesaan dan perkotaan ternyata masih memprihatinkan. Hal bisa dilihat dari akses air minum layak di Indonesia baru mencapai 87,75\%. Dan, hanya $6,8 \%$ penduduk yang sudah menikmati akses tersebut, sedangkan terdapat gap 80,95\% penduduk di tahun 2018 yang masih perlu ditingkatkan agar dapat menikmati akses dari akses layak menjadi akses aman. Secara keseluruhan sebanyak 93,2\% penduduk belum mendapatkan akses aman. Jika dikaitkan dalam kebutuhan pendanaan, estimasi pendanaan hingga tahun 2030 dapat lebih besar dari Rp238 triliun hal ini melihat dari perhitungan tingkat inflasi (Bappenas, 2019).

RPJMN 2020-2024 memperlihatkan capaian kinerja dari akses pelayanan air bersih yang masih belum cukup memuaskan pada periode pembangunan sebelumnya. Sehingga perlu peningkatan kualitas air yang digunakan sampai bisa dinyatakan ideal. Kondisi ini dikarenakan air yang dikonsumsi masyarakat kebanyakan masih dapat tercemar oleh bakteri maupun limbah yang mengandung B3 (bahan berbahaya dan beracun) sepertitimbal dan bakteriberbahaya. Tingkatkesehatan, keselamatan, dan kualitas hidup penduduk suatu wilayah sangat dipengaruhi oleh kualitas air dan kebersihan air. Hal ini menurut Sujagi et all (2017) juga memperlihatkan kondisi air bersih sangat berpengaruh terhadap pencemaran yang menurunkan kualitas air bersih.

Vijayan \& Mishra (2020), menyatakan bahwa rumah tangga memiliki akses ke sumber yang lebih baik penyediaan air belum tentu ber- konotasi dengan penggunaan air bersih. Cara penyimpanan dan pengolahan air juga akhirnya berperan dalam menentukan keamanannya. Hashemi (2020), menekankan bahwa dalam menyediakan air bersih berkelanjutan bagi masyarakat, memahami teknis, ekonomi, dan karakteristik sosial masyarakat sangat penting. Clasen \& Smith (2019) juga melihat minimnya pendidikan formal, sehingga banyak yang tinggal di perumahan berkualitas buruk di pedesaan serta daerah kumuh perkotaan, yang menyediakan sedikit akses ke air bersih, seringkali kurang gizi, dan dengan akses yang buruk ke perawatan kesehatan.

Berdasarkan Data Joint Monitoring Program WHO/UNICEF 2015, menyatakan bahwa sebanyak 51 juta penduduk di Indonesia masih menerapkan perilaku BAB sembarangan. Kondisi ini terlihat di beberapa daerah di mana mayoritas penduduk Indonesia masih terbiasa buang air besar sembarangan di tempat-tempat terbuka. Tahun 2019, kebiasaan BAB sembarangan di Indonesia masih di peringkat tertinggi ke-2, setelah India. Dan, kondisi ini masih terjadi. Begitu juga di Indonesia memiliki permasalahan sanitasi karena jamban baru dipakai oleh sebagai kecil masyarakat. Hal ini diperkuat dari data Water and Sanitation Program (WSP) tahun 2011 menyatakan kurang lebih 60 juta penduduk belum melaksanakan konsep sanitasi yang baik. Padahal sanitasi yang layak sangat berpengaruh terhadap kesehatan masyarakat. Penderita diare menurut data Kementerian Kesehatan tahun 2012 mengalami peningkatan dari 3,5 juta jiwa menjadi 4,5 juta jiwa. Sedangkan pemerintah pusat baru dapat memberikan 25 persen anggaran untuk program pengelolaan sanitasi di daerah. Sesuai RPJMN 2015-2019, pemerintah berkomitmen 
untuk melaksanakan program nasional Akses Universal Air Minum dan Sanitasi Tahun 2019 dengan capaian target 100\% (Suhono, 2016).

Sebagai pelayan publik sesuai dengan UU No 23 (2014), maka dalam mendorong pemerintah daerah maka program Pamsimas berkontribusi dalam penyediaan keuangan baik untuk sarana prasarana maupun pengelolaan, teknis, dan pengembangan kapasitas. Sehingga pemerintah daerah wajib untuk memberikan pelayan air minum dan sanitasi yang baik. Program Pamsimas dilakukan dengan pendekatan masyarakat di mana perlu kerja sama dengan masyarakat (dari berbagai latar belakang) dan pendekatan yang sesuai dengan kebutuhan masyarakat. Didasari pendekatan tersebut maka pelaksanakan selanjutnya terkait pemberdayaan masyarakat dalam rangka meningkatkan prakarsa, kepedulian serta partisipasi dalam pengambilan keputusan, perencanaaan, penyiapan, pelaksanaan, pengoperasian dan pemeliharaan sarana yang telah dibentuk, dan keberlanjutan kegiatan untuk meningkatkan kesehatan sekitar dan di lingkungan pendidikan.

Ruang lingkup kegiatan program Pamsimas mencakup 5 (lima) komponen proyek yaitu:

1. Pemberdayaan masyarakat dan pengembangan kelembagaan daerah dan desa.

2. Peningkatan perilaku higienis dan pelayanan sanitasi.

3. Penyediaan sarana air minum dan sanitasi umum.

4. Hibah insentif, dan

5. Dukungan teknis dan manajemen pelaksanaan program.

\begin{tabular}{|l|c|c|}
\hline \multicolumn{3}{c|}{ Tabel 1. Komposisi Pendanaan Program Pamsimas } \\
\hline \multicolumn{1}{c|}{ Sumber Dana } & Jumlah (Rp) & Persentase $(\%)$ \\
\hline APBN/Loan Bank Dunia & $192.500 .000,00$ & 70 \\
\hline APBD Kab/Kota & $27.500 .000,00$ & 10 \\
\hline Swadaya masyarakat & & 4 \\
\hline Tunai & $11.000 .000,00$ & 16 \\
\hline Tenaga dan material & $44.000 .000,00$ & 100 \\
\hline Total Dana Per Desa & $275.000 .000,00$ & Sumber : Pamsimas.org \\
\hline \multicolumn{2}{|c}{} \\
\hline
\end{tabular}

Tabel 2. Performance Sarana Air Minum Keberlanjutan 19 Januari 2014

\begin{tabular}{|l|c|}
\multicolumn{1}{|c|}{ Wilayah/Tingkat } & Indeks Performance (values) \\
\hline Desa Sudimara & 100 \\
\hline Kabupaten Banyumas & 88 \\
\hline Jawa Tengah 2 & 74 \\
\hline Nasional & 65 \\
\hline \multicolumn{2}{|c|}{ Sumber : Pamsimas.org } \\
\hline
\end{tabular}

Indikator performance berasal dari pencapaian indikator kinerja program Pamsimas tingkat kabupaten. Penilaian indeks performance memperhitungkan progres capaian kinerja dengan berbagai indikator kinerja tingkat kabupaten program Pamsimas seperti target jumlah penduduk yang dapat mengakses air bersih dan sanitasi, adanya rencana pembangunan wilayah juga mendukung percontohan dan penyesuaian kebutuhan dengan pendekatan Pamsimas dan ketercapaian tujuan. Desa Sudimara mendapatkan indeks yang baik sehingga program Pamsimas diharapkan benar-benar membawa dampak yang baik bagi ketersediaan air bersih di pedesasaan.

Pamsimas merupakan kegiatan yang memberikan dampak bagi kesehatan masyarakat. Kegiatan ini dilaksanakan oleh Kementerian Pekerjaan Umum sebagai executing agency bekerja sama dengan Kementerian Dalam Negeri dan Kementerian Kesehatan. Pamsimas secara umum akan memberikan peningkatan dalam pelayanan akses air minum dan sanitasi, terutama bagi warga miskin di desa dan kota pinggiran sehingga akan memberikan konsep penerapan kehidupan bersih dan sehat. Hal ini terwujudkan dengan pembangunan prasarana dan sarana air minum serta sanitasi berbasis masyarakat yang berkelanjutan dan diaplikasikan warga. Program ini adalah bentuk replikasi yang dikembangkan dan disesuaikan dengan kebutuhan masyarakat sehingga mampu mewujudkan tujuan.

Tujuan program Pamsimas menghasilkan masyarakat berlaku bersih dan sehat dengan peningkatan sarana yang dimiliki di pedesaan dan kota pinggiran melalui pelayanan air minum dan sanitasi. Sedangkan program Pamsimas juga memiliki tujuan umum antara lain (Ernawi \& Sutjiono, 2013):

1. Peningkatan kehidupan bersih dan sehat untuk pelaku program. 
2. Peningkatan akses dalam pelaksanaan program yang berkelanjutan sehingga dapat dikelola secara aktif.

3. Peningkatan kelembagaan dan pelaksanaan program.

4. Peningkatan komitmen dan efektifitas pemerintah dalam pelaksanaan program.

Target program Pamsimas merupakan warga, yang diutamakan dari kalangan bawah di pedesaan dan kota pinggiran. Hal tersebut terkait prevelensi penyakit air dan belum memperoleh program dalam pelaksanaan layanan air minum dan sanitasi dan membangun budaya bersih dan sehat.

Community-based Natural Resources Management (CBNRM) merupakan sebuah pergeseran paradigma dalam pengelolaan sumber daya alam dari model konvensional dan pendekatan top down menuju partisipasi masyarakat (Isyaku, Chindo, \& Ibrahim, 2011). Pendekatan ini merupakan proses desentralisasi yang bertujuan untuk memberikan wewenang pengambilan keputusan dan hak untuk mengontrol sumber daya alam kepada institusi akar rumput (Nhantumbo, Norfolk, \& Pereira, 2003).

CBNRM menjadi sebuah pelaksanaan dari pemilik lahan untuk mendapatkan akses dan memperoleh hak atas sumberdaya alam, merencanakan kegiatan secara kolaboratif dan transparan yang berarti berpartisipasi dalam pengelolaan sumberdaya alam, serta merasakan keuntungan finansial maupun keuntungan lainnya dari keterlibatan mereka. Pemilik lahan termasuk sebagai pemilik pribadi, swasta, maupun komunal. Berdasarkan hal tersebut maka terlihat adanya keharusan transfer ekonomi dan politik, sumber daya bernilai tinggi seperti kehidupan liar atau kehutanan serta perubahan dari terpusat menjadi kontrol masyarakat (Vijayan \& Mishra, 2020) (Child dan Lyman, dalam Gruber, 2010 ).

Pendapat ini juga disetujui oleh Wahyudin (2015) menerangkan bahwa CBNRM adalah sistem dalam me-manage sebuah sumberdaya alam, di mana masyarakat lokal berperan aktif di proses manajemennya. Manajemen bersifat multidimensi dari perencanaan, pelaksanaan, dan pemanfaatan hasil-hasilnya.
Dalam konsep pembangunan berbasis masyarakat, masyarakat berperan dalam keputusan, perencanaan, pelaksanaan, pengoperasian, dan pemeliharaan fasilitas program yang dikelola secara swakelola. Sehingga pemberian fasilitas oleh pelaksana program, khususnya dalam hal penyusunan rencana Program Jangka Menengah (PJM) air minum, kesehatan, dan sanitasi (ProAKSi) baik Rencana Kerja Masyarakat (RKM) maupun langkah dalam program Pamsimas (Ernawi \& Sutjiono, 2013).

Berdasarkan penelitian Emilia \& Hendrarto (2012), menyatakan bahwa dalam pengelolaan potensi suatu wilayah dengan baik akan memberikan dampak positif. Dampat positif ini terkait dengan kesejahteraan warga, wewenang pengambilan keputusan, akses terhadapa pendanaan serta konservasi sumber daya alam dan lingkungan. Hasil penelitian dari Boer \& Bressers (2013) juga menyatakan bahwa comanagement dapat menjadi sebuah langkah strategis dalam sebuah pengambilan keuntungan dari harapan untuk pengelolaan sumber daya. Peningkatan informasi mengenai sumber daya dan peningkatan penggunaan sumber daya juga berpengaruh dalam memahami co-management. Admaja (2010), berpendapat bahwa kontribusi program Pamsimas masih minim terhadap upaya penanggulangan kebutuhan akses air bersih dan sanitasi. Sehingga dampak yang dirasakan oleh masyarakat belum optimal.

Berdasarkan hal tersebut maka peneliti bertujuan untuk mengetahui dan menganalisis mengenai keoptimalan dan keberhasilan ketersediaan air bersih sebelum dan sesudah diterapkan di Desa Sudimara dan Efektivitas dari program Pamsimas yang diterapkan di Desa Sudimara.

\section{METODE}

Penelitian dilakukan di Desa Sudimara, Kecamatan Cilongok, Kabupaten Banyumas. Penelitian ini bersifat komparatif karena akan menganalisis manfaat sebelum dan sesudah berjalannya program Pamsimas terhadap masyarakat penerima manfaat. Penelitian komparatif merupakan penelitian deskriptif yang bertujuan untuk 
mencari tentang sebab akibat, dengan menganalisis faktor-faktor penyebab terjadinya ataupun munculnya suatu fenomena tertentu (Nasir, 2009).

Dalam penelitian ini, populasi terdiri dari 2 sekolah yang menerima manfaat program, 7 pengelola program Pamsimas dan masyarakat penerima manfaat sebanyak 320 orang. Sampel dari responden masyarakat penerima manfaat akan dipilih dengan metode proportionate random sampling sehingga akan terambil sampel sebanyak $50 \%$.

\begin{tabular}{|l|c|c|c|}
\hline \multicolumn{1}{|c|}{ Tabel 3. Teknik Proportionate Random Sampling di Desa Sudimara } \\
\hline Kawpling & Jumlah & Teknik & Ukuran Sampel \\
\hline Kon kawasan sasaran & 243 & $\frac{243}{320} \times 160$ & 122 \\
\hline Total & 77 & $\frac{77}{320}$ X160 & 38 \\
\hline \multicolumn{4}{|c|}{ Sumber : Data RKM Pamsimas Desa Sudimara } \\
\hline
\end{tabular}

Untuk mengetahui apakah terdapat perbedaan tingkat ketersediaan air bersih sebelum dan sesudah diterapkan di Desa Sudimara, maka dilakukan dengan Uji Binomial. Kedua unit sampling tersebut kemudian dibandingkan untuk melihat ada-tidaknya perbedaan.

Uji binomial digunakan untuk mengetahui ada atau tidak adanya perbedaan (kesamaan) rata-rata antara dua buah data. Pengujian ini merupakan uji statistik parametrik yang tentu saja harus memenuhi asumsi data berdistribusi normal dan apabila data tidak berdistribusi normal, uji statistik non parametrik lebih tepat digunakan.

Uji hipotesis:

$\mathrm{H}_{0}=$ Kedua varians populasi adalah sama (homogen)

$\mathrm{H}_{1}=$ Kedua varians populasi adalah tidak sama (tidak homogen)

Kriteria pengambilan hipotesis:

- Jika nilai probabilitas >0,05, maka $\mathrm{H}_{0}$ diterima

- Jika nilai probabilitas $<=0,05$, maka $\mathrm{H}_{0}$ ditolak

Penelitian ini juga untuk menganalisis efektivitas keberhasilan program Pamsimas yang diterapkan di Desa Sudimara, maka menggunakan rasio analisis efektivitas. Efektivitas adalah hu- bungan di antara output dan tujuan. Semakin besar kontribusi output pada pencapaian tujuan, maka bisa dikatakan efektif organisasi, program, atau kegiatan tersebut. Sehingga kegiatan atau program dinilai efektif jika output bisa memenuhi tujuan yang diharapkan atau dikatakan spending wisely.

$$
\text { Efektivitas }=\frac{\text { realisasi Pencapaian }}{\text { Target Pencapaian }}
$$

Departemen Dalam Negeri dengan Kepmendagri No.690.900-327 tahun 1996 mengkategorikan kemampuan efektivitas ke dalam lima tingkat efektivitas seperti di bawah ini:

\begin{tabular}{|l|c|}
\hline \multicolumn{2}{c|}{ Tabel 4. Kriteria Efektivitas } \\
\hline \multicolumn{1}{|c|}{ Kemampuan Keuangan } & Rasio Efektivitas \\
\hline Sangat Efektif & $>100$ \\
\hline Efektif & $>90-100$ \\
\hline Cukup Efektif & $>80-90$ \\
\hline Kurang Efektif & $>60-80$ \\
\hline Nasional & $<=60$ \\
\hline \multicolumn{2}{|c|}{ Sumber : Depdagri, Kepmendagri No. 690.900.327 tahun 1996, (Syamni, 2009) } \\
\hline
\end{tabular}

\section{HASIL dan PEMBAHASAN \\ Hasil}

Ketersediaan air bersih sebelum dan sesudah diterapkan di Desa Sudimara digambarkan dengan koordinasi responden dan indikator yang digunakan. Total jumlah responden adalah 320 penerima manfaat program Pamsimas, pengelola program Pamsimas, dan pihak-pihak yang dianggap mengetahui program Pamsimas di desa. Indikator tingkat keberhasilan program Pamsimas di Desa Sudimara meliputi 6 aspek yaitu: penerima manfaat di desa dapat mengakses air bersih sepanjang tahun, penerima manfaat dapat mengakses sarana sanitasi sepanjang tahun, adanya pemberdayaan masyarakat diukur melalui keterlibatan semua lapisan masyarakat (miskin, kaya, perempuan dan laki-laki) dalam pengelolaan program Pamsimas, penerima manfaat mengalami peningkatan hidup bersih dengan cuci tangan sebelum makan serta penerima manfaat beralih buang air besar di jamban dan sekolah memiliki sarana sanitasi yang layak dan digunakan oleh siswa

Untuk melihat ketersediaan air bersih sebe- 
lum dan sesudah diterapkan di Desa Sudimara dilakukan uji binomial. Uji binomial digunakan untuk menguji hipotesis dari suatu proporsi populasi yang berasal dari 1 sampel tunggal. Pengukuran data menggunakan 2 kategori. Kategori tersebut dilihat dengan Ya dan Tidak.

\begin{tabular}{|c|c|c|c|c|}
\hline \multicolumn{5}{|c|}{ Tabel 5. Hasil Uji Binomial Desa Sudimara } \\
\hline & \multicolumn{2}{|c|}{ Category } & N & $\begin{array}{l}\text { Asymp. Sig. } \\
\text { (2-tailed) }\end{array}$ \\
\hline \multirow[b]{2}{*}{ Aspek akses air bersih } & Kawasan sasaran & Ya & 143 & $.000^{\mathrm{a}}$ \\
\hline & $\begin{array}{l}\text { Non Kawasan } \\
\text { sasaran }\end{array}$ & Tidak & 17 & \\
\hline \multicolumn{3}{|l|}{ Total } & 160 & \\
\hline \multirow{2}{*}{$\begin{array}{l}\text { Aspek akses sarana } \\
\text { sanitasi }\end{array}$} & Kawasan sasaran & Ya & 152 & $.000^{\mathrm{a}}$ \\
\hline & $\begin{array}{l}\text { Non Kawasan } \\
\text { sasaran }\end{array}$ & Tidak & 18 & \\
\hline \multicolumn{3}{|l|}{ Total } & 160 & \\
\hline \multirow{2}{*}{$\begin{array}{l}\text { Aspek keterlibatan } \\
\text { masyarakat }\end{array}$} & Kawasan sasaran & $Y_{a}$ & 150 & $.000^{\mathrm{a}}$ \\
\hline & $\begin{array}{l}\text { Non Kawasan } \\
\text { sasaran }\end{array}$ & Tidak & 10 & \\
\hline \multicolumn{3}{|l|}{ Total } & 160 & \\
\hline \multirow{2}{*}{$\begin{array}{l}\text { Aspek peningkatan hidup } \\
\text { bersih }\end{array}$} & Kawasan sasaran & $Y a$ & 8 & $.000^{\mathrm{a}}$ \\
\hline & $\begin{array}{l}\text { Non Kawasan } \\
\text { sasaran }\end{array}$ & Tidak & 152 & \\
\hline \multicolumn{3}{|l|}{ Total } & 160 & \\
\hline \multirow{2}{*}{$\begin{array}{l}\text { Aspek peralihan buang } \\
\text { air besar di jamban }\end{array}$} & Kawasan sasaran & Ya & 160 & $.000^{\mathrm{a}}$ \\
\hline & $\begin{array}{l}\text { Non Kawasan } \\
\text { sasaran }\end{array}$ & - & - & \\
\hline \multicolumn{3}{|l|}{ Total } & 160 & \\
\hline \multirow{2}{*}{$\begin{array}{l}\text { Aspek kepemilikan } \\
\text { sarana sanitasi yang } \\
\text { layak di sekolah }\end{array}$} & Kawasan sasaran & Ya & 157 & $.000^{\mathrm{a}}$ \\
\hline & $\begin{array}{l}\text { Non Kawasan } \\
\text { sasaran }\end{array}$ & Tidak & 3 & \\
\hline \multicolumn{3}{|l|}{ Total } & 160 & \\
\hline
\end{tabular}

Tabel 6. Rasio Analisis Efektivitas Program Pamsimas

\begin{tabular}{|c|c|c|c|c|}
\hline Indikator & $\begin{array}{c}\text { Indikator } \\
\text { Keberhasilan }(\%)\end{array}$ & $\begin{array}{l}\text { Keterca- } \\
\text { paian }(\%)\end{array}$ & Rasio & Ket \\
\hline $\begin{array}{l}\text { Penerima manfaat di } \\
\text { desa dapat mengakses } \\
\text { air bersih sepanjang } \\
\text { tahun }\end{array}$ & 50 & 80 & 160 & $\begin{array}{l}\text { sangat } \\
\text { efektif }\end{array}$ \\
\hline $\begin{array}{l}\text { Penerima manfaat dapat } \\
\text { mengakses sarana } \\
\text { sanitasi sepanjang tahun }\end{array}$ & 50 & 80 & 160 & $\begin{array}{l}\text { sangat } \\
\text { efektif }\end{array}$ \\
\hline $\begin{array}{l}\text { Adanya pemberdayaan } \\
\text { masyarakat diukur } \\
\text { melalui keterlibatan } \\
\text { semua lapisan } \\
\text { masyarakat (miskin, } \\
\text { kaya, perempuan } \\
\text { dan laki-laki) dalam } \\
\text { pengelolaan program } \\
\text { Pamsimas. }\end{array}$ & 70 & 80 & 114 & $\begin{array}{l}\text { sangat } \\
\text { efektif }\end{array}$ \\
\hline $\begin{array}{l}\text { Penerima manfaat } \\
\text { mengalami peningkatan } \\
\text { hidup bersih dengan cuci } \\
\text { tangan sebelum makan. }\end{array}$ & 80 & 90 & 112 & $\begin{array}{l}\text { sangat } \\
\text { efektif }\end{array}$ \\
\hline $\begin{array}{l}\text { Penerima manfaat } \\
\text { beralih buang air besar } \\
\text { di jamban }\end{array}$ & 100 & 100 & 100 & efektif \\
\hline $\begin{array}{l}\text { Sekolah memiliki sarana } \\
\text { sanitasi yang layak dan } \\
\text { digunakan oleh siswa }\end{array}$ & 95 & 100 & 105 & $\begin{array}{l}\text { sangat } \\
\text { efektif }\end{array}$ \\
\hline
\end{tabular}

\section{Pembahasan}

Pada Tabel 5 memperlihatkan bahwa hasil proporsi responden memperlihatkan nilai keberhasilan program Pamsimas di Desa Sudimara tinggi. Berdasarkan tabel di atas, dapat dilihat bahwa aspek 1 yaitu "Penerima manfaat di desa dapat mengakses air bersih sepanjang tahun", di mana sebanyak 143 responden menjawab Ya dan 17 responden menjawab Tidak. Aspek 2 yaitu "Penerima manfaat dapat mengakses sarana sanitasi sepanjang tahun", di mana sebanyak 152 responden menjawab Ya dan 18 responden menjawab Tidak. Aspek "Adanya pemberdayaan masyarakat diukur melalui keterlibatan semua lapisan masyarakat (miskin, kaya, perempuan dan laki-laki) dalam pengelolaan program Pamsimas", di mana sebanyak 150 responden menjawab Ya dan 10 responden menjawab Tidak.

Aspek "Penerima manfaat mengalami peningkatan hidup bersih dengan cuci tangan sebelum makan", di mana sebanyak 152 responden menjawab Ya dan 8 responden menjawab Tidak. Aspek "Penerima manfaat beralih buang air besar di jamban", di mana sebanyak 160 responden menjawab Ya dan 0 responden menjawab Tidak. Aspek "Sekolah memiliki sarana sanitasi yang layak dan digunakan oleh siswa", di mana sebanyak 157 responden menjawab Ya dan 7 responden menjawab Tidak. Pada semua aspek nilai Sig $<0,05$, sehingga dapat disimpulkan bahwa proporsi responden yang menyatakan Ya atau berhasil di Desa Sudimara lebih besar. Dengan demikian dapat disimpulkan bahwa terdapat perbedaan ketersediaan air bersih sebelum dan sesudah diterapkan program Pamsimas di Desa Sudimara.

Hal ini juga sesuai dengan penelitian yang dilakukan oleh Fitriyani \& Rahdriawan (2015), di mana keberhasilan setiap indikator menjadi cerminan keoptimalan dalam pemanfaatan air bersih program Pamsimas. Hasil penelitian ini juga sesuai dengan Cory \& Taylor (2017), yang menyatakan bahwa bentuk pengeluaran air akan berdampak pada pengeluaran kesehatan dan pengeluaran makanan dengan asumsi pendapatan tetap. Hal ini berarti bahwa penggunaan air akan meningkatkan kesehatan yang akan mengurangi pengeluaran kesehatan 
Sedangkan pada Tabel 6, indikator pertama yaitu "Penerima manfaat di desa dapat mengakses air bersih sepanjang tahun", ditetapkan 50\% masyarakat dapat mengakses air bersih. Dalam realisasinya, program Pamsimas di Desa Sudimara telah berhasil melampaui target dengan capaian, di mana $80 \%$ masyarakat dapat mengakses air bersih sehingga dapat dikatakan bahwa program Pamsimas di Desa Sudimara sangat efektif dalam menyediakan akses air bersih.

Indikator kedua yaitu "Penerima manfaat dapat mengakses sarana sanitasi sepanjang tahun" ditetapkan 50\% masyarakat dapat mengakses sarana sanitasi. Dalam realisasinya program Pamsimas di Desa Sudimara telah berhasil melampaui target dengan capaian $80 \%$ masyarakat dapat mengakses air bersih sehingga dapat dikatakan bahwa program Pamsimas di Desa Sudimara sangat efektif dalam menyediakan sarana sanitasi.

Indikator ketiga yaitu "Adanya pemberdayaan masyarakat" ditetapkan 70\% masyarakat dapat terlibat dalam kegiatan pengelolaan program Pamsimas. Dalam realisasinya program Pamsimas di Desa Sudimara telah berhasil melampaui target dengan capaian $80 \%$ masyarakat terlibat sehingga dapat dikatakan bahwa program Pamsimas di Desa Sudimara sangat efektif dalam memberdayakan masyarakat.

Indikator keempat yaitu "Penerima manfaat mengalami peningkatan hidup bersih dengan cuci tangan sebelum makan" ditetapkan $80 \%$ masyarakat meningkat kualitas sanitasinya dengan kebiasaan cuci tangan. Dalam realisasinya program Pamsimas di Desa Sudimara telah berhasil melampaui target dengan capaian $90 \%$ masyarakat meningkat kualitas sanitasinya, sehingga dapat dikatakan bahwa program Pamsimas di Desa Sudimara sangat efektif dalam meningkatkan kualitas sanitasi.

Indikator kelima yaitu "Penerima manfaat beralih buang air besar di jamban" ditetapkan $100 \%$ buang air besar di jamban. Dalam realisasinya program Pamsimas di Desa Sudimara telah berhasil mencapai target dengan capaian $100 \%$ masyarakat telah buang air besar di jamban, sehingga dapat dikatakan bahwa program Pam- simas di Desa Sudimara efektif.

Indikator keenam yaitu "Sekolah memiliki sarana sanitasi yang layak dan digunakan oleh siswa" ditetapkan 95\% sekolah memiliki sarana sanitasi yang baik. Dalam realisasinya program Pamsimas di Desa Sudimara telah berhasil melampaui target dengan capaian 100\% sekolah memiliki sarana sanitasi yang baik, sehingga dapat dikatakan bahwa program Pamsimas di Desa Sudimara sangat efektif dalam meningkatkan kualitas sarana sanitasi di sekolah.

Jadi dapat dilihat bahwa rasio efektivitas program Pamsimas dari semua indikator keberhasilan menunjukkan angka yang efektif. Sehingga dapat disimpulkan bahwa program Pamsimas di Desa Sudimara sudah efektif dalam penyelenggaraannya. Penelitian dari Destarian \& Pigawati (2015) menyatakan bahwa sebelum pembangunan sarana penting bagi masyarkat untuk memiliki pemahaman dalam pengelolaan sehingga menimbulkan rasa kepemilikan bersama. Dampaknya masyarakat akan dapat memutuskan biaya operasional yang tepat dan mampu berkelanjutan dalam pengelolannya. Hal ini akan dapat menjadi ukuran efekvifitas dalam sebuah kegiatan.

\section{SIMPULAN}

Program Pamsimas berhasil memenuhi ketersediaan sarana air bersih di Desa Sudimara, Kecamatan Cilongok, Kabupaten Banyumas. Hal ini didasarkan pada hasil uji binomial yang sudah dilakukan terhadap enam aspek yang ditetapkan sebagai indikator keberhasilan program Pamsimas berhasil dalam semua aspek. Sedangkan program Pamsimas berdasarkan rasio efektifitas dari enam indikator yang digunakan terlihat lima indikator sangat efektif dan satu indikator dinyatakan efektif. Dengan demikian dapat dinyatakan bahwa program Pamsimas ini memenuhi tujuan dan harapan yang ditetapkan.

\section{PENGHARGAAN}

Terima kasih kami berikan kepada semua pihak yang berperan dalam penyelesaian penelitian. Terutama kepada pemberi dana DRPM 
skema penelitian dosen pemula. Serta tak lupa kepada perangkat Desa Sudimara dan Universitas Tidar yang telah memberikan kesempatan peneliti untuk kelancaran dan keberhasilan penelitian.

\section{DAFTAR PUSTAKA}

Undang-Undang No.23 tahun 2014. Pemerintahan Daerah, pelayanan air minum dan sanitasi telah menjadi urusan wajib Pemerintah Daerah.

Admaja, C. S. (2010). Dampak Implementasi Program Penyediaan Air Minum dan Sanitasi Berbasis Masyarakat Terhadap Upaya Penanggulangan Kebutuhan Akses Air Minum dan Sanitasi Masyarakat Miskin ( Studi Kasus di Kabupaten Sragen tahun 2008).

Boer, C. De, \& Bressers, H. (2013). Water resource co-management and sustainable regional development. Management Research Review, 36(12), 1238-1251.

Clasen, T., \& Smith, K. R. (2019). Let the "A " in WASH Stand for Air: Integrating Research and Interventions to Improve Household Air Pollution ( HAP ) and Water, Sanitation and Hygiene. Environmental Health Perspectives, 127(2), 1-6.

Cory, D. C., \& Taylor, L. D. (2017). On the Distributional Implications of Safe Drinking Water Standards. Journal Benefit Cost Abalysis, 8(1), 49-90.

Destarian, C., \& Pigawati, B. (2015). Evaluasi Program Pamsimas di Kelurahan Jabungan Kecamatan Banyumanik. Jurnal Teknik PWK, 4(4), 530-541.

Emilia, F., \& Hendrarto, B. (2012). Community Based Natural Resources Management (CBNRM) di Desa Keseneng, Kecamatan Sumowono, Kabupaten Semarang. Prosiding Seminar Nasional Pengelolaan Sumberdaya Alam Dan Lingkungan, (September), 65-69.

Ernawi, I. S., \& Sutjiono, D. (2013). Pedoman Umum Pengelolaan Program Pamsimas.

Fitriyani, N., \& Rahdriawan, M. (2015). Evaluasi Pemanfaatan Air Bersih Program Pamsimas di Kecamatan Tembalang. Jurnal Pengembangan Kota, 3(2), 80-89.
Gruber, J. S. (2010). Key Principles of CommunityBased Natural Resource Management: A Synthesis and Interpretation of Identified Effective Approaches for Managing the Commons. Enviromental Management, 45, $52-66$.

Hashemi, S. (2020). Sanitation Sustainability Index: A Pilot Approach to Develop a Community-Based Indicator for Evaluating Sustainability of Sanitation Systems. Journal Sustainability, 12, 1-12.

Isyaku, U., Chindo, M., \& Ibrahim, M. (2011). Assessing Community-based Natural Resources Management at Lake Naivasha, Kenya. Enviromental and Natural Resources Research, 1(1), 106-116.

Nasir, M. (2009). Metode Penelitian. Jakarta: Ghalia Indonesia.

Nhantumbo, I., Norfolk, S., \& Pereira, J. (2003). Community Based Natural Resources Management in Mozambique: A Theoretical or Practical Strategy for Local Sustainable Development? The Case Study of Derre Forest Reserve Isilda Nhantumbo.

Suhono, Da. (2016). Pedoman Umum Program Pamsimas. Jakarta: Sekretariat Pamsimas.

Syamni, G. (2009). Analisis Kontribusi dan Efektifitas Komponen Pendapatan Asli Daerah terhadap Anggaran Pendapatan Belanja Daerah Kabupaten Aceh Utara Title. Universitas Malikussaleh.

Vijayan, B., \& Mishra, U. (2020). Associating State of Water and Sanitation with Childhood diarrhoea: Anomalies and Contradictions Anomalies in Analyzing Water and Sanitation Data. Experimental Results, 1(e6), 1-10.

Wahyudin, Y. (2015). "Community Based Management (CBM)." Retrieved from www. researchgate.net/publication/252661503. 